\title{
Proximate Composition and Energy Value Analysis of Five Varieties of Malting Barley
}

\author{
Cecilia Castillo ${ }^{1, ~ *}$, Gabino García ${ }^{1}$, Adrián Hernández ${ }^{1}$, Mauro Zamora ${ }^{2}$ \\ ${ }^{1}$ Genetic Resources and Productivity-Seed Production Program, Postgraduate College Montecillo Campus. Texcoco, México \\ ${ }^{2}$ National Barley Breeding Program, National Institute of Research in Forestry, Agriculture and Livestock (INIFAP), Valley of México \\ Experimental Station, Texcoco, México
}

\section{Email address:}

castillo.cecilia@colpos.mx (C. Castillo),garciag@colpos.mx (G. García), helasamy@colpos.mx (A. Hernández), zamora.mauro@inifap.gob.mx (M. Zamora)

${ }^{*}$ Corresponding author

\section{To cite this article:}

Cecilia Castillo, Gabino García, Adrián Hernández, Mauro Zamora. Proximate Composition and Energy Value Analysis of Five Varieties of Malting Barley. International Journal of Food Science and Biotechnology. Vol. 4, No. 2, 2019, pp. 35-39. doi: 10.11648/j.ijfsb.20190402.11

Received: May 3, 2018; Accepted: June 1, 2018; Published: May 8, 2019

\begin{abstract}
Malting barley is an important crop in the world due to its high nutritional value that imparts great benefits to health. The aim of this study was to evaluate the proximate analysis and energy value of five varieties of barley malting of Mexican origin. Results showed that malting barley varieties have on average high amounts of total carbohydrates (76.84\%), protein $(12.47 \%)$, fiber $(5.65 \%)$, fat $(2.67 \%)$, ash $(2.36 \%)$, and moisture $(10.34 \%)$ and provide lots of energy to humans. Although the five varieties have the same nutrients, each variety stands out for its particular characteristics. The Esperanza variety had a higher value of carbohydrates, considering it important for nutrition and the malting industry. The Esmeralda variety showed high protein content; this parameter is significant for the feed industry and human nutrition. Armida is the variety with the highest fat content and at the same time provides greater amount of energy. The varieties with higher fiber content and ash were Adabella and Alina, respectively.
\end{abstract}

Keywords: Malting Barley, Proximate Analysis, Nutritional Value, Energy Value

\section{Introduction}

Barley (Hordeum vulgare), like any other cereal, belongs to the grass family and is one of the major ancient world's crops $[1,2]$. Cereals are staple foods and are very important nutritionally talking. They have been part of the human diet since historic times [3]. The chemical and nutritional composition of cereal crops vary widely and depends on several factors, namely the environmental and soil conditions, variety, fertilizer management, agricultural practices such as seeding rate $[2,4,5]$. In their natural form (as a whole grain), cereals are a significant source of energy, carbohydrates, protein, fat, and fiber. They also contain a range of micronutrients and bio-active components notably vitamins and minerals $[6,7,8]$.

Barley is the fourth most cultivated cereal crop in the world after maize, rice and, wheat [9]. The barley grain is mainly exploited as feed as well as raw material for malt production; only a small fraction is used for human food purposes $[1,10]$.

Barley is classified as a spring or winter crop (depending on the season in which it is sown in the field), two-row or six-row (referring to the arrangement of the seeds on the rachis), hulled or hulless (presence or absence of hull tightly adhering to the grain), and malting (high starch content) or feed (high protein content) by end-use type [10, 11].

This study was conducted in order to know the proximate composition and energy value of five varieties of malting barley and to determine their nutritional value and the most appropriate use in the industry.

\section{Materials and Methods}

\subsection{Sample Collection}

Varieties of malting barley (Adabella, Alina, Armida, Esmeralda, and Esperanza) were provided by the National Institute of Research in Forestry, Agriculture and Livestock 
(INIFAP), of the Bajío Region in Celaya, Guanajuato. These materials were stored in a warehouse at $14.8^{\circ} \mathrm{C}$ and relative humidity of $56.5 \%$ until analysis.

Samples of each variety were ground to a fine powder using a grinder.

\subsection{Proximate Composition}

Proximate analyses (moisture content, crude protein, crude fat, crude fiber and, ash content) were carried out according to the standard AOAC methods (2005) [12]. Total carbohydrates were calculated by difference method [13]. The analyses were performed in triplicate.

\subsubsection{Determination of Moisture}

Moisture content was measured by oven dry method (at $100-105^{\circ} \mathrm{C}$ for $2 \mathrm{~h}$ ). About $2.0 \mathrm{~g}$ of each well homogenized sample were accurately weighed in a clean, dried crucible $\left(\mathrm{W}_{1}\right)$. The crucible remained in an oven until the constant weight of dry matter was obtained. Then, the sample was cooled in desiccators and finally weighed again $\left(\mathrm{W}_{2}\right)$. The moisture content $(\% \mathrm{M})$ was calculated by the following formula:

$$
\% M=\left(\frac{W_{1}-W_{2}}{\text { Weight of sample }}\right) \times 100
$$

\subsubsection{Determination of Crude Protein}

Protein content of powdered samples was determined by micro-kjeldahl method. About $0.3 \mathrm{~g}$ of dried samples was weighed and placed within test tubes. Then, $0.5 \mathrm{~g}$ of digesting mixed catalyst and $3 \mathrm{ml}$ of concentrated $\mathrm{H}_{2} \mathrm{SO}_{4}$ was added to each sample in the digestion tube. The mixture was placed on a heater to start digestion until clear green color was obtained. The digests were allowed to cool and diluted with distilled water, and then the content was transferred into micro distillation apparatus. About $10 \mathrm{ml}$ of $40 \% \mathrm{NaOH}$ was added to each digest in the distillation chamber. A conical flask containing $6 \mathrm{ml}$ of $4 \%$ boric acid solution was placed under the condenser. The distillation continued until $30 \mathrm{ml}$ of the distillate was trapped in the boric acid solution. The distillates were then titrated with $0.1010 \mathrm{~N} \mathrm{HCl}$ and the values were recorded. Nitrogen $(\% \mathrm{~N})$ and crude protein $(\% \mathrm{P})$ percentages were calculated through the formula:

$$
\% N=\frac{(m L H C l x N x 1.4)}{\text { Weight of sample }}
$$

Where:

$\mathrm{N}=$ Normality of $\mathrm{HCl}$

$$
\% P=\% N \times 6.25
$$

\subsubsection{Determination of Crude Fat}

For the determination of crude fat, the ether extract method was used. Following this procedure, $1.0 \mathrm{~g}$ of moisture-free sample was introduced in a fat-free thimble and then placed in the extraction chamber. Petroleum ether was added in the extraction equipment. A receiving beaker was weighed $\left(\mathrm{W}_{1}\right)$ and placed into the apparatus. The heater was turned on for evaporating solvent and the condenser water valve opened to recondense.

After extraction, the solvent beaker with fat and thimbles with fat-free samples were removed from the apparatus. The beaker was transferred to an oven at $105^{\circ} \mathrm{C}$ for $24 \mathrm{~h}$ and cooled in a desiccator. Then, the beaker was weighed $\left(\mathrm{W}_{2}\right)$ in an analytical balance. The crude fat percent or ether extract (\% E. E.) was determined by the following formula:

$$
\% \text { E.E. }=\left(\frac{W_{2}-W_{1}}{\text { Weight of sample }}\right) \times 100
$$

\subsubsection{Determination of Crude Fiber}

The analysis of crude fiber consisted in the treatment of the sample with $1.25 \% \mathrm{H}_{2} \mathrm{SO}_{4}$ and $1.25 \% \mathrm{NaOH}$ followed by drying in oven. At first, $1.5 \mathrm{~g}$ moisture and fat-free sample was weighed and transferred to a beaker. Two hundred milliliters of $1.25 \% \mathrm{H}_{2} \mathrm{SO}_{4}$ was added to each sample. Then, the beaker was put to boil in a fiber determiner. Two hundred milliliters of distilled water was added and filtered in a constant weight filter paper $\left(\mathrm{W}_{1}\right)$. The same procedure was followed using $200 \mathrm{ml}$ of $1.25 \% \mathrm{NaOH}$. The sample was transferred into clean, dry and weighted crucibles. The crucibles were placed in an oven at $105^{\circ} \mathrm{C}$ for $8 \mathrm{~h}$. Then, the sample was cooled in a desiccator, the dried residue was weighed $\left(\mathrm{W}_{2}\right)$ and placed in a muffle furnace. Finally, the crucibles with ash residue were weighed $\left(\mathrm{W}_{3}\right)$. Crude fiber (\% C. F.) was calculated using the following formula:

$$
\% C . F .=\left(\frac{W_{2}-W_{3}-W_{1}}{\text { Weight of sample }}\right) \times 100
$$

\subsubsection{Determination of Ash}

The ash content was determined using a muffle furnace. About $1.0 \mathrm{~g}$ of sample of each variety was weighed in constant weight crucibles $\left(\mathrm{W}_{1}\right)$ and placed in a muffle furnace at $600^{\circ} \mathrm{C}$ for $24 \mathrm{~h}$. Then the crucibles were removed, cooled in desiccator and weighed $\left(\mathrm{W}_{2}\right)$. The ash percentage content was determined using the following formula:

$$
\% \text { Ash }=\left(\frac{W_{1}-W_{2}}{\text { Weight of sample }}\right) \times 100
$$

\subsubsection{Determination of Carbohydrates}

The estimation of carbohydrates content [13] or the nitrogen-free extract [14] was done by adding moisture, crude protein, crude fat, ash, and crude fiber, and subtracting from 100 , as follows:

$\%$ Carbohydrates $=100-($ moisture + crude protein + crude fat + ash + crude fiber)

\subsection{Energy Value}

Total energy values were calculated by multiplying lipids by 9 , proteins and carbohydrates by 4 and expressed in $\mathrm{kcal} / 100 \mathrm{~g}$ [15].

\subsection{Statistical Analysis}

All analyses of each variety were done in triplicate. The 
data were subjected to analysis of variance (ANOVA), and the means were compared by Tukey Test at 5\% probability using SAS (Statistical Analysis System) Version 9.0 [16].

\section{Results and Discussion}

The proximate composition of malting barley seeds is presented in Table 1. Significant differences among malting barley varieties were observed for moisture, crude protein, crude fat, and carbohydrate parameters, while crude fiber and ash content showed non-significant differences.

The moisture content ranged from $10.20 \%$ to $10.73 \%$, which is within the optimal range of humidity (6-15\%) to ensure good storage [17]. The low moisture content in crop grains is adequate to maintain or enhance their physical, physiological and nutritional quality $[18,19]$. On the flip side, high moisture content as a consequence of fluctuating relative humidity and temperature of the environment leads to storage problems because it promotes fungal and insect growth. Seeds with sufficient amount of water into them trigger metabolic processes, including respiration, germination and gene transcription and translation [20, 21, 22].

Table 1 shows that carbohydrates represent the main fraction of malting barley seed composition (75.61 $77.45 \%$ ). The Esperanza variety showed the highest carbohydrate percentage while the Armida variety had the lowest. The total mean carbohydrate value of five malting barley varieties analyzed in this study was $76.84 \%$, slightly higher than $75 \%$ of total carbohydrate reported by other authors [3]. Malting barley seeds have significant amounts of carbohydrates (Figure 1), mainly starch [23] in comparison with fruit seeds such as melon which contains 7.22\% [24], oilseeds such as mustard with $16.29 \%$ [25] and legumes which in general contain $60 \%$ carbohydrates [26].

Table 1. Proximate composition and energy value of five varieties of malting barley. Variety.

\begin{tabular}{llllllll}
\hline \multicolumn{7}{l}{ Parameters (\%) } & \\
& Moisture & Crude Protein & Crude Fat & Crude Fiber & Carbohydrates & Ash content & Energy Value (kcal/100 g) \\
\hline Adabella & $10.22 \mathrm{a} \pm 0.03$ & $11.30 \mathrm{c} \pm 0.06$ & $3.36 \mathrm{a} \pm 0.29$ & $6.10 \mathrm{a} \pm 0.02$ & $77.02 \mathrm{a} \pm 0.44$ & $2.22 \mathrm{a} \pm 0.17$ \\
Alina & $10.20 \mathrm{a} \pm 0.07$ & $12.48 \mathrm{~b} \pm 0.07$ & $2.93 \mathrm{a} \pm 0.22$ & $5.30 \mathrm{a} \pm 0.13$ & $76.72 \mathrm{ab} \pm 0.26$ & $2.57 \mathrm{a} \pm 0.04$ & 383.02 \\
Armida & $10.20 \mathrm{a} \pm 0.10$ & $12.53 \mathrm{~b} \pm 0.16$ & $3.71 \mathrm{a} \pm 0.06$ & $5.75 \mathrm{a} \pm 0.25$ & $75.61 \mathrm{~b} \pm 0.12$ & $2.40 \mathrm{a} \pm 0.03$ & 385.95 \\
Esmeralda & $10.34 \mathrm{a} \pm 0.15$ & $13.29 \mathrm{a} \pm 0.10$ & $1.62 \mathrm{~b} \pm 0.24$ & $5.39 \mathrm{a} \pm 0.05$ & $77.39 \mathrm{a} \pm 0.08$ & $2.31 \mathrm{a} \pm 0.02$ & 377.30 \\
Esperanza & $10.73 \mathrm{~b} \pm 0.09$ & $12.77 \mathrm{~b} \pm 0.17$ & $1.75 \mathrm{~b} \pm 0.21$ & $5.71 \mathrm{a} \pm 0.53$ & $77.45 \mathrm{a} \pm 0.50$ & $2.32 \mathrm{a} \pm 0.13$ & 376.63 \\
\hline
\end{tabular}

*Mean \pm standard deviation, $\mathrm{n}=3$. Means with different letters in a column are significantly different $(\alpha=0.05)$.

Protein content in malting barley seeds revealed that the Esmeralda variety had the highest value (13.29\%), followed by Esperanza (12.77\%), Armida (12.53\%), Alina (12.48\%), and Adabella (11.30\%). The protein content in the analyzed samples is consistent with other authors [10], who indicate that the protein percentage for barley grain varies from $10 \%$ to $17 \%$.
For crude fat, the analyzed seeds showed acceptable levels that were in the range of $1.62 \%-3.71 \%$, having on average of $2.67 \%$. The Esmeralda and Armida varieties had the lowest and the highest values, respectively. The values are similar with other research findings, where lipid content in barley was from $2 \%-3 \%[11,27]$.

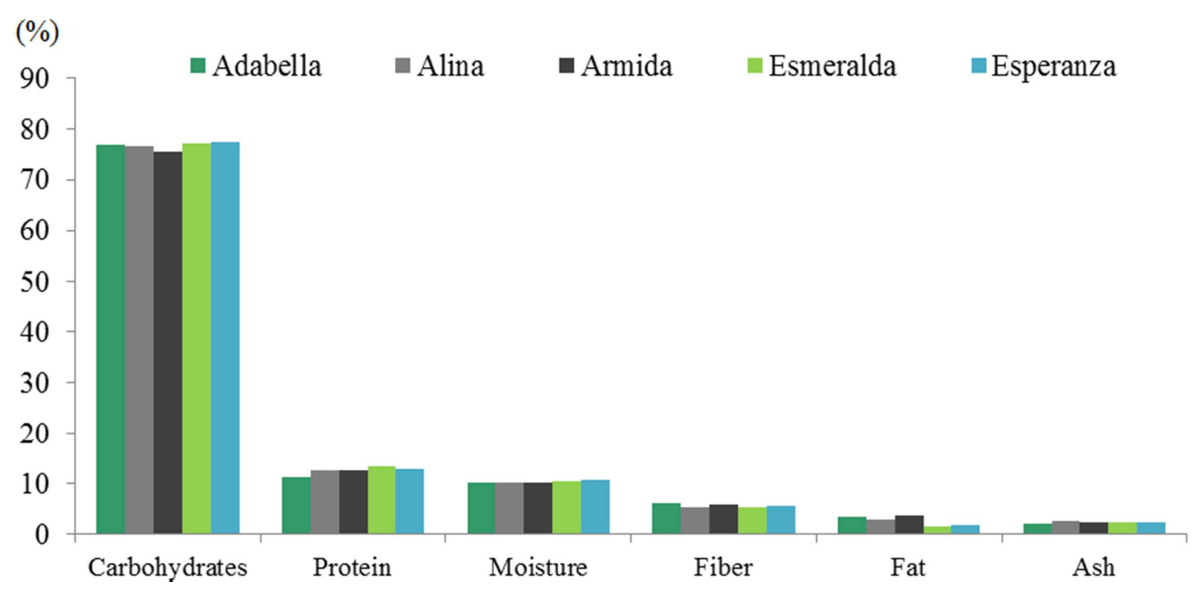

Figure 1. Comparison of the nutritional content of five varieties of malting barley.

Crude fiber showed that Adabella had the highest percentage of $6.10 \%$ while the Armida, Esperanza, Esmeralda, and Alina varieties showed less crude fiber content $(5.75 \%, 5.71 \%, 5.39 \%$, and $5.30 \%$, respectively). These values are higher than those reported in other studies, in which the authors obtained crude fiber content in barley grains in the range of $4.74 \%$ to $5.01 \%$ [28]. The growing interest in barley as food is because several studies have revealed barley to be an excellent source of fiber, recognized it as functional and nutritious cereal grain for the reason that it provides beneficial effects on the health of the consumers [13, 29, 30]. 
Ash represents the concentration of mineral contents in a food product. This study showed that ash percentage was between $2.22 \%-2.57 \%$. These data agree with the findings from other studies, where a mineral content in the range of $1.5 \%-2.5 \%$ was reported for whole barley grains $[10,11]$.

The energy value calculated in the malting barley varieties was in average of $381.31 \mathrm{kcal} / 100 \mathrm{~g}$. This value is higher than that reported by other authors [31, 32], who confirm that barley grains provide 332.47 to $354 \mathrm{kcal} / 100 \mathrm{~g}$. All cereal grains have high energy values coming mainly from the starch, but, also from the fat and protein portions, which together provides energy to the organism [6].

\section{Conclusion}

The five varieties of malting barley showed high nutritional content; they are a good source of carbohydrates, protein, and fiber mainly. One of the most important nutrients present in cereal seeds is carbohydrates and in malting barley they represent $76.84 \%$ of the total grain weight. According to this, the malting barley varieties analyzed here are suitable for the malting process, highlighting the Esperanza variety for its highest carbohydrate content $(77.45 \%)$. Protein is a valuable parameter for livestock feed and also important in the brewing industry. The varieties studied here have on average $12.47 \%$ protein emphasizing the Esmeralda variety with the highest content of this nutrient (13.29\%). The five varieties also contain other nutrients like fiber, that are important to treat some diseases in human beings; crude fiber represented on average $5.65 \%$ of the total grain weight and the Adabella variety had the highest content $(6.10 \%)$.

\section{Aknowledgements}

The first author appreciates the financial support of National Council on Science and Technology (CONACyT), México (grant 44200, register number 238012).

\section{References}

[1] Newman, C. W. and Newman, R. K. (2006). A brief history of barley foods. Cereal Foods World, 4-7.

[2] Riahi, E. and Ramaswamy, H. S. (2003). Structure and composition of cereal grains and legumes," In: Handbook of postharvest technology: cereals, fruits, vegetables, tea and spices, G. S. Vijaya, A. Chakraverty, A. S. Mujumdar, Eds. Marcel Dekker, New York.

[3] McKevith, B. (2004). Nutritional aspects of cereals. British Nutrition Foundation, Nutrition Bulletin, 29: 111-142.

[4] Edney, M. J., O’Donovan, J. T., Turkington, T. K., Clayton, G. W., Mckenze, R., Juskiw, P., Lafond, G. P., Brant, S., Grant, C. A., Harker, K. N., Johnson, E. and May, W. (2012). Effects of seeding rate, nitrogen rate and cultivar on barley malt quality. Journal Science Food and Agriculture, 92 (13): 26722678.
[5] Cabrera, D. F. M., González, M. S., Juárez, M. A., Leija, M. P and Benavides, M. A. (2018). Plant Nutrition and Agronomic Management to Obtein Crops with Better Nutritional and Nutraceutical Quality. In: A. Grumezescu and A. M. Holban. (Eds.). Therapeutic Foods. Handbook of Food Bioengineering (vol. 8, pp. 99-140). San Diego, United States. Academic Press In.

[6] Sarwar, M. H., Sarwar, M. F., Sarwar, M., Qadri, N. A. and Moghal, S. (2013). The importance of cereals (Poaceae: Gramineae) nutrition in human health: A review. Journal of Cereals and Oilseeds, 4 (3): 32-35.

[7] Koehler, P. and Wieser, H. (2013). Chemistry of cereal grains. In: M. Gobbetti and M. Gänzle (Eds.). Handbook of Sourdough Biotechnology (pp. 11-45). Springer, Boston, MA.

[8] Papageorgiou, M. and Skendi, A. (2018). Introduction to cereal processing and by-products. In: C. M. Galanakis (Ed.). Sustainable Recovery and Reutilization of Cereal Processing By-Products (Fisrt Edition, pp. 1-25). Cambridge, United Kingdom. Woodhead Publishing Ltd.

[9] Faostat, (2014). FAO Statistics Division. Food and Agriculture Organization of the United Nations.

[10] Das, M. and Kaur, S. (2015). Status of barley as a dietary component for human. Research \& Reviews. Journal of Food and Dairy Technology, 25-30.

[11] Baik, B. K. and Ullrich, S. E. (2008). Barley for food: Characteristics, improvement, and renewed interest. Journal of Cereal Science, 48 (2): 233-242.

[12] AOAC, (2005). Official Methods of Analysis of AOAC International. $18^{\text {th }}$ Edition, AOAC International, Gaithersburg, USA.

[13] Ali, S., Nazir, S., Usman, S., Nasreen, Z., Kalsoom, U. and Inam, T. (2014). Study on the biochemical effects of barley fiber on the hypercholesterolaemic rats. African Journal of Plant Science, 8 (5): 237-242.

[14] Serna-Saldivar, S. O. (2012). Cereal Grains. Laboratory Reference and Procedures Manual. CRC Press, Taylor \& Francis Group.

[15] FAO. (2002). Food energy - methods of analysis and conversion factors. Report of a technical workshop. FAO Food and Nutrition Paper No. 77. Rome.

[16] SAS Institute. (2002). Statistical Analysis System Version 9. 0. North Carolina, USA.

[17] Taruvinga, C., Mejia, D. and Sanz, J. (2014). Appropiate Seed and Grain Storage Systems for Small-scale Farmers. Food and Agriculture Organization of the United Nations.

[18] Atici, O., Agar, G., and Battal, P. (2007). Influence of long term storage on plant growth substance levels, germination and seedling growth in legume seeds stored for 37 years. Indian Journal of Plant Physiology, 12 (1): 1-5.

[19] Batey, I. (2017). Maintaining Grain Quality During Storage and Transport. In: C. Wrigley, I. Batey and D. Miskelly. Cereal Grains. Assessing and Managing Quality (Second Edition, pp. 571-590). Australia. Woodhead Publishing.

[20] FAO. (2011). Rural structures in the tropics. Design and development. Rome. 
[21] Afzal, I., Bakhtavar, M. A., Ishfaq, M., Sagheer, M. and Baribusa, D. (2017). Maintaining dryness during storage contributes to higher maize seed quality. Journal of Stored Products Research, 72: 49-53.

[22] Nonogaki, M and Nonogaki, H. (2017). Germination. In: B. Thomas, D. J. Murphy and B. G. Murray (Eds.). Encyclopedia of Applied Plant Sciences (Second Edition, Vol. 1, pp. 509512). Amsterdam, Boston. Academic Press.

[23] Zhu, F. (2017). Barley Starch: Composition, Structure, Properties, and Modifications. Comprehensive Reviews in Food Science and Food Safety, 16: 558-579.

[24] Jacob, A. G., Etong, D. I. and Tijjani, A. (2015). Proximate, Mineral and Anti-nutritional Compositions of Melon (Citrullus lanatus) Seeds. British Journal of Research, 2 (5): 142-151.

[25] Sharif, R. H., Paul, R. K., Bhattacharjya, D. K. and Ahmed, K. U. (2017). Physicochemical characters of oilseeds from selected mustard genotypes. Journal of the Bangladesh Agricultural University, 15 (1): 27-40.

[26] Maphosa, I. and Jideani, V. A. (2017). The Role of Legumes in Human Nutrition. In: M. Chavarri. Functional Food.
Improve Health through Adequate Food (pp. 103-109). Croatia. InTech.

[27] Åman, P., Hesselman, K. and Tilly, A. C. (1985). The variation in chemical composition of Swedish barleys. Journal of Cereal Science, 3 (1): 73-77.

[28] Wilczewski, E. (2014). Content of macroelements and crude fiber in grain of spring barley cultivated in different agronomic conditions. Acta Scientiarum Polonorum, Agricultura, 13 (1): 73-83.

[29] Šterna, V., Zute, S. and Jâkobsone, I. (2015). Grain composition and functional ingredients of barley varieties created in Latvia. Proceedings of the Latvian Academy of Sciences, 69 (4):158-162.

[30] Hashemi, J. M. (2015). Biomedical Effects of Barley-A Review. New York Science Journal, 8 (3): 52-55.

[31] USDA, (2018). Food Composition Databases. Available from: http://ndb.nal.usda.gov (2 May 2018)

[32] Kumari, R. and Kotecha, M. (2015). Physicochemical and nutritional evaluation of Yava (Hordeum vulgare Linn.). International Research Journal of Pharmacy, 6 (1): 70-72. 